\title{
The Perceptions Towards the Implementation of Online Learning: A Study on ESP Teachers and Students of UNP
}

\author{
Fadhilah Fadhilah ${ }^{*}$ and Hamzah Hamzah ${ }^{2}$
}

\author{
${ }^{12}$ English Department, FBS Universitas Negeri Padang, Padang, Sumatra Barat 25131, Indonesia \\ *Corresponding author. Email: dhila.chanas@gmail.com
}

\begin{abstract}
Online learning has been an important part of education and is claimed to offer unique benefits in the learning process. Although the online learning management system has been used by almost all of the academic community as one of the facilities in teaching and learning, some people still do not believe that online classes will revolutionize classroom. This research attempt to elaborate some insights about the perceptions of teachers and students toward the implementation of online learning in the English for Specific Purposes (ESP) class of Universitas Negeri Padang (UNP). This research was conducted in the Department of Sports Coaching of UNP. The data was carried through an e-questionnaire, which was sent to the students and the teacher to see their perceptions toward the implementation of online learning. Results reveal that some of the participants have positive perceptions toward the implementation of online learning, despite some challenges they faced, it can be a helpful tool to learn language. Hopefully, this research could be the reference for education stakeholders and also the developers who want to create or develop the application to be used for online learning, especially in English subject.
\end{abstract}

\section{Keywords: Online learning, perception, English for Specific Purposes, teachers, students}

\section{INTRODUCTION}

The ESP (English for Specific Purposes) term refers to the teaching of a specific genre for students with a definite, specific goal, or field of study. ESP is centred more on language in context than on teaching grammar and language structures and is designed to meet the leaners' specific needs and reasons for learning. People learn foreign languages when they have opportunities to use, understand or work with them. The English language is taught as a subject related to the learners' real needs and wishes in a particular field of human activity and it usable in the employment context. The materials used for ESP courses should be authentic materials and the language which students encounter in these materials should be exactly what they meet in real life. It is the teachers' responsibility to make a rigorous selection of materials. The selection has in view the real needs of the students' study or future job requirements.

Since the Corona virus disease (Covid-19) has emerged to all over the world, without exception to Indonesia, some places have implemented online teaching and learning by using online platforms, such as Zoom, Cisco Webex, Skype, Google Meet, Adobe Connect, Whatsapp Group, Moodle, Facebook, etc. Therefore, the Ministry of Education and Culture
(Kemendikbud) of Indonesia has decided to implement the teaching and learning system by teaching from home and learning from home, to protect the health and safety all of education unit residents. The methods and media are carried out by distance learning or online learning, which makes the use of online platforms is abundant now.

In Indonesia, some schools and universities has implemented the online learning management system, but it is restricted, but most of them only for students who join the non-regular program and not all schools or institutes provide it. In Universitas Negeri Padang (UNP), the online learning management system has been used for years by almost all of academic community as one of facilities in teaching and learning. It is 'E-learning by Moodle' which provide teachers and students in doing their work, but still the use of it was not as massive as today, in pandemic situation. Some lecturers find it difficult to teach via online platforms, they have no idea how to use it and they prefer to use the traditional ways to collect students' works, namely papers, scrapbook, or something like that. Same case with lecturers, students also find some issues in online learning, such as some technical problem like unstable network connection, low internet package data, low lack 
of understanding the online materials, low self-learning motivation, and not all of students who have proper gadget to be used for online learning.

The quality of the internet in some places in Indonesia, especially in West Sumatra, is still low and not many people understand how to use technologies for teaching and learning via online platforms. Interaction and engagement must thrive between the learners, instructor and the content or course material. According to Charalambos \& Michalinos [1] the interaction with the various types of materials allows the learners to develop a deeper understanding of the content.

Some studies have been conducted to find out perception regarding online English learning faced by English teachers and students. Khatoony and Nezhadmehr [2] revealed that many teachers have assumed it is not just technology that supports learners during this crucial event; it is seen as enhancing English learning. Teaching is the first required and vital forum to provide meaningful education for language teachers.

Then, Auma and Achieng [3] mentioned that despite several obstacles that affected its performance, the study results showed that teachers had a positive view toward online teaching. Bachiri and Oifaa [4] argued the use of ICT tends to change the dynamics of classrooms, especially the interactions between teachers and students.

In addition, Sahu [5] suggested universities should have plan a road map to accommodate admissions for future academic sessions, in addition to the current difficulties in handling teaching and assessment during the COVID-19 outbreak. Kulal and Nayak [6] indicated that students are comfortable with online classes and provide enough support from teachers, but do not believe that online classes will revolutionize classroom teaching. Martin, Stamper, and Flowers [7] suggested that students should be motivated to focus on their skills as online learners, their time management, networking and practical skills. Muthuprasad [8] revealed that the students found accessibility and convenience of online classes to be an appropriate option, while issues concerning internet connectivity in rural areas made the use of online learning a challenge for students.

\section{METHODS}

This research belongs to descriptive research with a qualitative approach. The subjects of this study were 23 students and one teacher from English application class for sports coaching. The questionnaire was used to examine the ESP teacher and students' perception on online learning. This research was particularly relevant where information is required directly from those experiencing that phenomenon under investigation.

The questionnaire were distributed online through google form to the teacher and students since it was covid-19 pandemic and could not meet people in person. There were 35 questions consisted of 3 indicators to be filled by participants. The researcher will calculate the score of teachers and students' by using Likert scale. In this type of questionnaire, the score can be seen as follows:

Tabel 1. Degree of Agreement

\begin{tabular}{|c|c|}
\hline Degree of Agreement & Score \\
\hline Strongly Agree & 4 \\
\hline Agree & 3 \\
\hline Disagree & 2 \\
\hline Strongly Disagree & 1 \\
\hline
\end{tabular}

The researcher will count every thick from every degree of agreement by using the formula:

\section{T $x$ Pn}

$\mathrm{T}=$ the number of respondents who chose the option Pn $=$ the score of Likert

All of the result will be calculated to obtain total score from this formula. In order to interpret the score, the researcher will identify the lowest score $(\mathrm{X})$ and the highest score (Y) to be input to index (\%) formula:

$$
\%=\frac{\text { Total score }}{y} \times 100
$$

\section{RESULT AND DISCUSSION}

The results of this research related to the perception of ESP teacher and students regarding the implementation of online learning in UNP. The results were obtained from 23 students and one teacher from English application class for sports coaching. Online learning was implemented since the covid-19 pandemic was spreading all over the place. The data from the equestionnaire via Google Form was calculated by the formula to get the percentage of each statement on its indicators which could be interpreted descriptively.

\section{Chart 1. The Percentage of Students' Perception per Indicators}

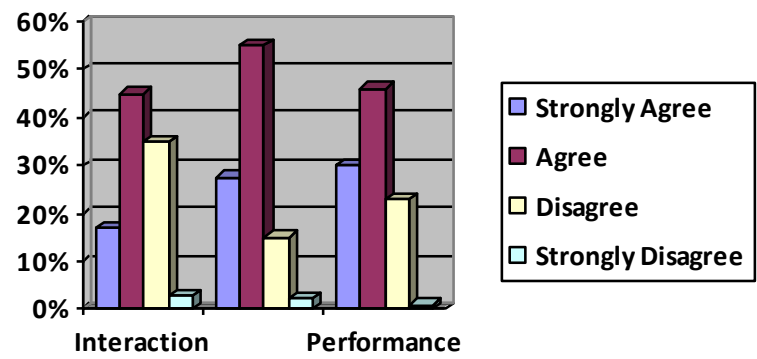

The chart above shows that the percentage of the results regarding the perception of ESP students toward the implementation of online learning. Based on the chart, in relation with the first indicator, it can be seen that most of the students agreed that interaction in online learning was running well, even though some issues often detain the process of learning.

The second indicator shows that most of students agreed that attendance in an online class was very important so that they always tend to presence in every meeting. They also utilize the chance to give response to 
the teacher and to other students. They felt motivated to be actively involved in every activity in online class.

The third indicator shows that most of the students agreed that through online learning they could be more creative in doing their work. They became more discipline with the deadline time to submit their work. They felt convenience in getting feedback from the teacher toward their work. Thus, based on those indicators, the majority of the students shared a positive perception regarding online learning. They might get some barriers in doing online learning, but they still could solve it as well.

\section{Chart 2. The Percentage of Teacher's Perception per}

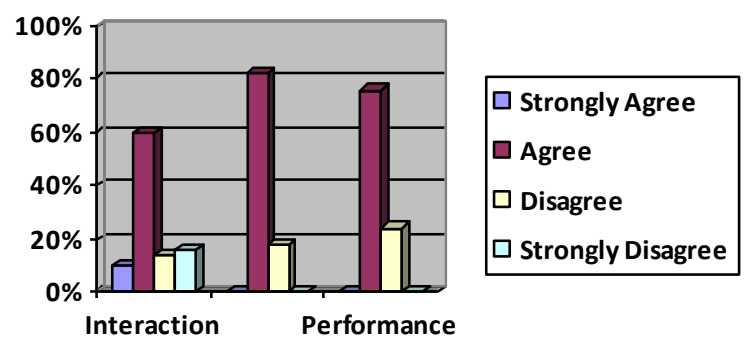

\section{Indicators}

From the teacher points of view, he thought that the teaching and learning process should be done in offline class. Even though the online learning gave him chance to be flexible in time, but when it came to interaction, he felt there still obstacles in doing that, such as noise that came from bad internet connection or the materials could not be shown through online platforms. So, there still need some improvement in the development of online platforms, especially the internet connection.

\section{CONCLUSION}

Based on the results above, it can be concluded the participants shared a positive perception toward the implementation of online learning in English class. However, not every part that can be delivered well since there are many obstacles in using online platforms. Online learning is a good alternative both of teacher and student cannot meet directly in person, especially during pandemic. Hopefully, the developer of internet connection and online platforms could improve the needs in doing online learning. In addition, hopefully everyone who actively involved in online learning like teacher and student must have the ability to utilize the technology as well.

\section{ACKNOWLEDGMENTS}

The researcher would like to thank to Allah Ta'ala who blessing me in writing this article. Also, thanks to the English Education Study Program, Universitas Negeri Padang, where the researcher gets a lot of knowledge from studying there. The warmest appreciation is given to the researcher's supervisor, Dr. Hamzah, MA, MM, for his guidance and constructive advices in finishing this article.
Finally, for the researcher's parents, for all support, they give to finish this article.

This paper is far from being perfect, but hopefully this research could be the reference for education stakeholders and also the developers who want to create or develop the application to be used for online learning, especially in English subjects.

\section{REFERENCES}

[1] Charalambos, V., \& Michalinos, Z. (2004). The design of online learning communities: Critical issues. Education Media International, 41(2), 135143.

[2] Khatoony, S., \& Nezhadmehr, M. (2020). EFL teachers' challenges in integration of technology for online classrooms during Coronavirus (COVID-19) pandemic in Iran. AJELP: Asian Journal of English Language and Pedagogy, 8, 116.

[3] Auma, O.M., \& Achieng, O.J. (2020). Perception of teachers on effectiveness of online learning in the wake of COVID-19 pandemic. IOSR Journal of Humanities and Social Science (IOSR-JHSS). 25(6). 19-28.

[4] Bachiri, H., \& Oifaa, T. (2020, September). The Role of ICT in the Teaching of Productive Skills in English during COVID-19: Teachers' Perceptions and Obstacles. In Linguistic Forum-A Journal of Linguistics (Vol. 2, No. 2, pp. 35-44).

[5] Sahu, P. (2020). Closure of universities due to coronavirus disease 2019 (COVID-19): Impact on education and mental health of students and academic staff. Cureus, 12(4).

[6] Kulal, A., \& Nayak, A. (2020). A study on perception of teachers and students toward online classes in Dakshina Kannada and Udupi District. Asian Association of Open Universities Journal.

[7] F. Martin, B. Stamper, and C. Flowers, "Examining student perception of readiness for online learning: Importance and confidence," Online Learn. J., vol. 24, no. 2, pp. 38-58, 2020, doi: 10.24059/olj.v24i2.2053.

[8] Muthuprasad, T., Aiswarya, S., Aditya, K.S., \& Jhaa, G. K. (2021). Students' perception and preference for online education in India during COVID -19 pandemic. Social Science and Humanities Open. Volume 3, Issue 1, doi: https://doi.org/10.1016/j.ssaho.2020.100101. 